(6)

\section{OPEN ACCESS}

'Department of Orthopaedics, University Hospital Waterford, Waterford, Ireland

${ }^{2}$ Department of Trauma and Orthopaedics, University Hospital Waterford, Waterford, Ireland

Correspondence to

Dr Robin McManus,

robinmcmanus@rcsi.ie

Accepted 14 January 2018

\title{
Radial nerve injury following dry needling
}

\author{
Robin McManus, ${ }^{1}$ May Cleary $^{2}$
}

\section{SUMMARY}

A 27-year-old secretary presented to an orthopaedic outpatients department with a 1-month history of left wrist drop following dry needling. On insertion of a needle, she reported spasms in her left hand followed by a wrist drop. An MRI scan was normal. Electromyogram and nerve conduction studies showed a neuropraxia of the left radial nerve. She was referred to a hand therapist for splinting and intensive hand therapy; however, her symptoms remain unchanged.

\section{BACKGROUND}

Dry needling and acupuncture are commonly practised methods of pain management. In Ireland dry needling is performed by physiotherapists. It is considered a safe treatment. ${ }^{1}$

\section{CASE PRESENTATION}

A 27-year-old secretary presented to an orthopaedic outpatients department with a 1-month history of left wrist drop following dry needling.

The patient attended physiotherapy occasionally for deep tissue massage and dry needling for shoulder pain. On this particular occasion, as the physiotherapist inserted a needle, she reported that she felt spasms in her left hand followed by a wrist drop. The needle was inserted in the lateral

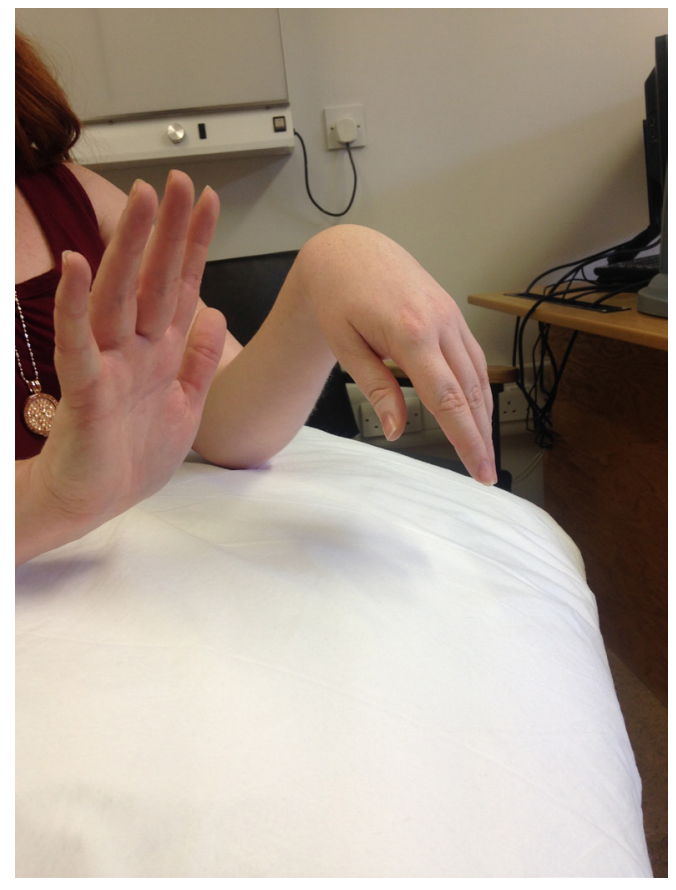

To cite: McManus $\mathrm{R}_{\text {, }}$ Cleary M. BMJ Case Rep Published Online First: [please include Day Month Year]. doi:10.1136/bcr-2017221302
Figure 1 The patient was asked to extend both wrists, and the figure 1 shows that the patient was unable to extend her left wrist. aspect of her arm, approximately at the level of the junction of the middle and distal third of her left humerus. The patient reported that the needle was applied with equal vigour to other needles applied that day. A filiform needle $0.25 \mathrm{~mm}$ in diameter and $50 \mathrm{~mm}$ in length was used.

The patient attended the emergency department where an MRI scan of her arm showed no evidence of pathology at or around her left humerus.

\section{INVESTIGATIONS}

Nerve conduction studies and an electromyogram (EMG) were performed following orthopaedic review. This revealed a neuropraxia of her left radial nerve at the spiral groove. EMG of the left triceps muscle was normal. She was referred to a neurologist, who could find no contributing neurological conditions or cervical radiculopathy. Follow-up nerve conduction studies and an EMG showed no signs of recovery. The patient continues to have symptomatic weakness.

\section{TREATMENT}

The patient was referred to a hand therapist for splinting. Despite intensive hand therapy, she continues to show no signs of improvement and has consistent left wrist drop (figure 1).

\section{DISCUSSION}

Dry needling is the insertion of a needle into a myofascial trigger point. A trigger point is a hyperirritable spot in the skeletal muscle or its fascia. ${ }^{2}$ The needle can be inserted into the superficial tissue above the trigger point or into the trigger point. ${ }^{1}$ The depth to which the needle is inserted depends on the muscle being treated.

Injury to the radial nerve can present in a variety of ways. The more common would include following a fracture to the shaft of the humerus, compression of the arm (Saturday night palsy/honeymoon palsy) or following lead poisoning.

We report that there is little or no published evidence to suggest a radial nerve injury following

\section{Learning points}

- While rare, the complications of dry needling can have serious implications for the patient.

- The anatomy of the area being treated should be familiar to the practitioner before undertaking the procedure.

- Healthcare practitioners who perform this procedure should be familiar with the complications and should undertake informed consent prior to the procedure. 
dry needling. An extensive review of the literature shows reports of complications in dry needling and acupuncture such as pneumothorax, cardiac tamponade, spinal epidural haematoma, abdominal visceral injury, and median and fibular nerve injury. ${ }^{3}$ Despite this, complications are rare; however, healthcare professionals who offer this service should be familiar with the anatomy of the region that they are treating.

Contributors Clinical work-up and all the work surrounding the write-up of this case have been under the stewardship of MC. MC is the acting guarantor for this work. RM is an orthopaedic SHO at University Hospital Waterford. He reviewed the patient in the clinic, has followed the patient's investigation results, performed a literature search on this topic and wrote the case report under the guidance of MC.

Funding This research received no specific grant from any funding agency in the public, commercial or not-for-profit sectors.

Competing interests None declared.

Patient consent Obtained.

Provenance and peer review Not commissioned; externally peer reviewed.

Author note This case was presented to the Department of Trauma and Orthopaedics in University Hospital Waterford. This patient is under the care of MC,
Consultant Orthopaedic Surgeon.

Open Access This is an Open Access article distributed in accordance with the Creative Commons Attribution Non Commercial (CC BY-NC 4.0) license, which permits others to distribute, remix, adapt, build upon this work non-commercially, and license their derivative works on different terms, provided the original work is properly cited and the use is non-commercial. See: http://creativecommons.org/ licenses/by-nc/4.0/

(c) BMJ Publishing Group Ltd (unless otherwise stated in the text of the article) 2018. All rights reserved. No commercial use is permitted unless otherwise expressly granted.

\section{REFERENCES}

1 Brady S, McEvoy J, Dommerholt J, et al. Adverse events following trigger point dry needling: a prospective survey of chartered physiotherapists. J Man Manip Ther 2014:22:134-40.

2 Travell J, Simons D, Simons L. Myofascial pain and dysfunction: the trigger point manual. 2nd edn. USA: Lippincott Williams \& Williams, 1999:5.

3 Peuker E, White A, Ernst E, et al. Traumatic complications of acupuncture. Arch Fam Med 1999;8:553-8.

4 Witt CM, Pach D, Brinkhaus B, et al. Safety of acupuncture: results of a prospective observational study with 229,230 patients and introduction of a medical information and consent form. Forsch Komplementmed 2009:16:91-7.

Copyright 2017 BMJ Publishing Group. All rights reserved. For permission to reuse any of this content visit

http://group.bmj.com/group/rights-licensing/permissions.

BMJ Case Report Fellows may re-use this article for personal use and teaching without any further permission.

Become a Fellow of BMJ Case Reports today and you can:

- Submit as many cases as you like

- Enjoy fast sympathetic peer review and rapid publication of accepted articles

- Access all the published articles

- Re-use any of the published material for personal use and teaching without further permission

For information on Institutional Fellowships contact consortiasales@bmjgroup.com

Visit casereports.bmj.com for more articles like this and to become a Fellow 